\title{
Urban renewal in post-industrial districts: the example of Lyon Metropolis
}

\section{Lydia Coudroy de Lille, Caroline Bouloc}

\begin{abstract}
Urban renewal issues in France are very often discussed with reference to the demolition or renovation of large-scale housing estates. But these issues also concern former industrial areas which have their own distinct architectural, social, and economic difficulties. This article aims to present analysis of these differences using the example of two case studies in the Lyon metropolitan area, the second largest agglomeration in France. First, we outline the background of urban policy in France and Lyon in particular, together with mapping "priority geography" of urban policy in Lyon. Our two case studies, La Saulaie and Carré de Soie, are located in suburbs of the metropolis. Through our analysis of the social and spatial features of these two renewal projects which are currently under way, we demonstrate that urban renewal policies in France are multi-layered, and that the case of Lyon illustrates especially robust engagement on the part of local authorities. Tackling poverty and isolation are the priorities in La Saulaie. In Carré de Soie, the challenges are to create a public transportation hub, a new housing market, and to attract companies to this new secondary centre. We also show that urban renewal operations are not limited to the areas defined by the "priority geography".
\end{abstract}

Key words: urban renewal, urban policy, former industrial areas, "priority geography", Lyon metropolitan area

\section{Introduction}

The history of cities is one of perpetual destruction, rehabilitation, the adaptation of the existing buildings, and the building of new ones. Sometimes the process of building, which usually occurs spontaneously one building after another is, at other times, conducted by public authorities into an integrated programme, targeting coherent and designed areas. Urban renewal has been undertaken in a great number of European cities, including in France in the last decades, because some districts are recognized as suffering from serious problems and therefore deserving special attention from public authorities. This need for renewal or regeneration, regardless of the term used, often comes at the end of a cycle of urban development: for example, after the construction of large prefabricated housing estates, or after a phase of urbanization that has itself resulted from industrialization. This article will focus on districts usually called post-industrial, i.e. those characterized by having an industrial past, in which the decline, the displacement, or the coversion of industry left a legacy of difficulties. We selected districts in communes which development was closely (if not solely) due to the location of industrial facilities on the outskirts of a big city in the ninetieth and 
twentieth centuries. These industrial suburbs are indeed more often than not monofunctional, their population is less diverse, poorer to those posed to residential areas, and thus face similar difficulties.

Literature on urban renewal in France has mostly focussed on the impacts of urban renewal in large housing estates [Droste, Lelévrier and Wassenberg 2014; Kaczmarek 2017], or in central areas where urban regeneration is suspected of fuelling gentrification [Appert, Drozdz 2010; Lees, Ferreri 2016]. Indeed, in the 1970s and 1980s, urban renewal first targeted old, run-down central districts, and only more recently, large housing estates built between 1950 and 1970. This literature often analyses how urban regeneration has brought about changes in urban governance. Initially considered the emergence of "urban struggles" in the 1970s, that is, conflicts concerning the destruction of old districts in Paris, Grenoble and other cities [Castells 1975]. After this, it took a critical stance to the dynamics between strong state involvement and citizens' participation in the current programmes to demolish and reconstruct large housing estates [Donzelot, Epstein 2006; Epstein 2013]. Nevertheless, with its repeated emphasis on residential projects, research has paid less attention to industrial or post-industrial areas [Edelblutte 2006].

This article will focus on districts in which local development policies are currently playing out. We will therefore not attempt to predict the effects of urban renewal in industrial areas, but instead we will try to expose its scopes and aims in the wider context of urban renewal in the metropolitan area of Lyon. We have adopted a qualitative methodology: we have collected statistical data which will enable us to undertake a multilevel diagnosis of the case studies, information from national and local reports, documents about urban renewal projects, and designed inventory maps of the areas covered by these projects. Before developing our analysis, however, we will begin by outlining the national and metropolitan conceptions and tools for urban renewal.

\section{Urban renewal in France and in Lyon}

\section{French urban policy: a historical background}

The French Urban Policy ${ }^{1}$ was born in the late 1980s and has undergone many changes in the current century, but one element has been stable: it has always been a "place-based" policy thus implementing a "priority geography" [Bourdon et al. 2013; Blanc 2007; Fol 2013]. The same debate occurs in regional policies and in economic geography [O'Brien et al. 2015; Gill 2010]: should we help individuals or communities and do we prefer a space-neutral and "people-based" policy or target areas (regions, districts) in which social difficulties are particularly concentrated and provide a "space-based" policy? In France for historical reasons,

\footnotetext{
${ }^{1}$ City politics.
} 
mainly thanks to a long tradition of regional planning on the national scale ${ }^{2}$, it was assumed that transforming the territory, the material structure of space, would enable planners to mitigate, if not to eradicate, concentrations of social disadvantages. This policy therefore selects "priority districts" (quartiers prioritaires) according to varying and gradated criteria established during the 1990s. From the beginning of urban policy, a distinction was made between the terms "renovation" and "renewal", a distinction which underpins a more technical differentiation than a political one. Renovation (rénovation) applies only to physical change, such as demolition and reconstruction of buildings and dwellings, or simply their rehabilitation. The term renewal (renouvellement) was introduced in 1999 by the interministerial urban committee ${ }^{3}$ and refers to a more complex set of actions. It encompasses not only the physical renovation of residential buildings, but also the construction of public infrastructure (leisure resorts, sports or cultural complexes, etc.), of public spaces, and social components (such as employment, education, health, and justice) [Le Garrec 2014]. In 2003, the National Programme of Urban Renovation was launched together with the National Agency of Urban Renovation $\left(\mathrm{ANRU}^{4}\right.$ ) which finances and coordinates this policy in 490 districts, including Projects of Urban Renovation (PRU areas). With a budget of up to $€ 45$ billion, $€ 12$ billion of which were made available by the ANRU; these projects targeted a population of 4 million. The main objectives were to reduce social inequalities between territories, improve living conditions, and produce social and urban diversity. The PRU programme is famous for the demolition of about 150,000 dwellings and the reconstruction of more or less the same number. In 2014, a new map of priority districts was designed: this comprises 1,300 districts, out of which 216 are in a more critical situation and need to be dealt with by the New National Program of Urban Renewal (NPNRU areas). The single criterion of concentration of socially deprived households has been used to determine this new "priority geography". This new programme also emphasizes the cooperation of inhabitants in targeted areas. It is less ambitious than the previous programme, having a budget of $€ 20$ billion, out of which only $€ 5$ billion come directly from the ANRU's funds. Today, the term urban renewal is an umbrella word in French - just like urban regeneration in English - for all types of transformations to dilapidated areas, including old industrial ones [Chaline 1999]. During the twentieth century, areas targeted by urban policy have been mostly large housing estates, some of them being the scene of so-called "urban riots" in French suburbs [Body-Gendrot 2007]. Meanwhile, post-industrial areas, including in small and medium-size cities, were given less attention in urban policy [Edelblutte 2006]. The reach of the districts and cities targeted by the NPNRU, however, demonstrates a readjustment of the "priority geography" to incorporate such areas.

\footnotetext{
${ }^{2}$ Territory Development.

${ }^{3}$ Interministerial Urban Committee.

${ }^{4}$ National Agency of Urban Renovation.
} 


\section{Lyon metropolitan area: a social geography}

Lyon is the second agglomeration in France (1.3 million inhabitants) and is located at the confluence of the Saône and Rhône rivers. The territorial collectivity named Metropolitan Lyon is made up of 59 communes, out of which the commune of Lyon itself is only $48 \mathrm{~km}^{2}$ and encompasses $38 \%$ of the metropolitan population. The social geography of the metropolitan area has its origins in the location of the industrial belt (automotive, petrochemical, etc.) mostly on the left bank of the Rhône - i.e. in the Southern and Eastern parts of the agglomeration - because raw materials were imported by boat, train and pipelines in the Rhone valley. The industrial and logistical specialization of the Eastern and Southern parts of the Metropolis continues to this day. Suburbs with a particular social makeup tend to be located in the West, where suburban agriculture and residential property have always been prevalent. Like many large cities in France, the population of municipal Lyon decreased in the 1980s; but this period is now over. Large-scale investment in public infrastructure, the increased availability of housing, and a generally positive economic outlook go some way in explaining the attractiveness of the city and indeed of the whole metropolis, which population grew by 6\% between 2011 and 2016. Unlike other large cities in France, however, broadly speaking Lyon does not face very serious issues of poverty or unemployment. Nevertheless, the social geography of the metropolis highlights a strong and persistent imbalance between East and West, coupled with pockets of poverty, all of which the urban policy is supposed to tackle.

\section{Urban policy in metropolitan Lyon}

Lyon was one of the first cities in France to face concerns about urban policy because its suburbs were the site of urban riots in 1979 in large housing estates built in the 1960s and 1970s in the Eastern and Southern communes, mainly Vénissieux and Vaulx-en-Velin [Stouten, Rosenboom 2013]. In metropolitan Lyon, the National Programme of Urban Renovation (PNRU) launched in 2003 planned to demolish and rebuild about 6,000 dwellings, to revitalize 8,000 , and to secure access to 12,700 others. This programme has been funded by various sources (Table 1), mainly local and regional authorities (accounting for 35\%, in blue on Fig. 1), HLM owners (32\%) and the ANRU (22\%). Public funds have also been joined by private investment. The EU alone provided up to $€ 5$ million. Compared to the distribution of funds of the PNRU on a national scale, the contribution of the ANRU is the same (France: $23 \%$ ) and the HLM owners pay less in Lyon (33\% as opposed to $44 \%$ in France), but local authorities are much more involved (the share of communes, metropolis, department, regions is $24 \%$ in France as a whole, but $38 \%$ in Lyon).

The programme of "priority geography" in Lyon changed in 2014 in line with a nationwide policy, which sought to target its efforts on a smaller number of areas (Figs. $2 \& 3$ ). ${ }^{5}$

${ }^{5}$ Loi de programmation pour la ville et la cohésion urbaine 2014-173 (Framework Act on Town Planning and Urban Cohesion), 21 February 2014. According to this law, the list of priority areas of the urban policy was published by the decree 2014-1750 on 30 December 2014. 
Table 1. Funding of the National Programme of Urban Renovation in Lyon Metropolitan Area (2004-2014)

\begin{tabular}{|l|r|}
\hline & Milions $€$ \\
\hline State & 5 \\
\hline Department & 118 \\
\hline Region & 69 \\
\hline Lyon metropolis & 205 \\
\hline Communers & 123 \\
\hline HLM owners & 471 \\
\hline Equity & 2 \\
\hline ANRU & 316 \\
\hline CDC (public bank) & 2 \\
\hline EU & 5 \\
\hline Others & 129 \\
\hline Total & 1,446 \\
\hline
\end{tabular}

Source: Coudroy de Lille, 2018. Métropole de Lyon, 2015

It is still concentrated in the industrial south-eastern part of the agglomeration where large housing estates had been built. Altogether urban policy has oversight over 76 districts, out of which 37 Quartiers prioritaires de la Politique de la Ville (QPV, "priority districts of the urban policy") are recognized (and funded) by the State, on the sole criterion that they demonstrate a concentration of poverty (Table 2). 158,000 inhabitants, i.e. $12 \%$ of the population of Lyon metropolitan area, live in QPVs. The New National Programme of Urban Renewal (NPNRU 2015-2024) encompasses 14 of the QPV districts in which architectural and urbanistic actions, such as demolition/reconstruction operations which were initiated in the previous National Programme of Urban Renewal (PNRU 2004-2014), will be continued. Out of the 14 NPNRU districts, eight are distinguished as a national priority, because they present the highest degree of difficulties, and receive more funds. Others are of regional priority and funded by the region. The 29 Quartiers en Veille Active (QVA, "districts under active watch") used to be QPVs before 2015 but fell victim to the emphases of priority geography. Their revitalisation relies on local authorities' funds alone. 


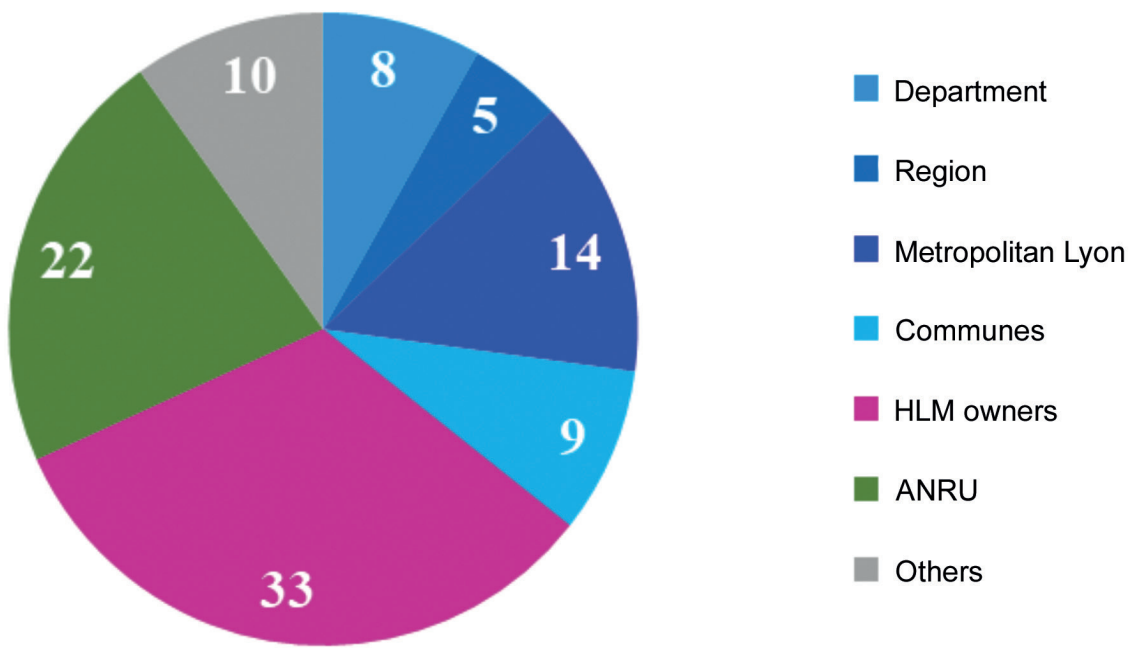

Fig. 1. Funding of the National Programme of Urban Renovation in Lyon Metropolitan Area (2004-2014) (in \% of total amount)

Source: Coudroy de Lille, 2018. Métropole de Lyon, 2015

Table 2. Typology of areas involved in urban policy in metropolitan Lyon

\begin{tabular}{|c|c|c|c|c|c|}
\hline \multirow{2}{*}{\multicolumn{3}{|c|}{ Districts concerned the urban policy }} & \multicolumn{2}{|c|}{ Priority actions } & \multirow{3}{*}{ 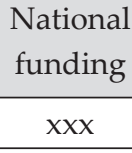 } \\
\hline & & & \multirow{2}{*}{$\frac{\text { Social }}{x \mathrm{xx}}$} & \multirow{2}{*}{$\frac{\text { Urbanistic }}{\mathrm{xx}}$} & \\
\hline \multirow{3}{*}{$37 \mathrm{QPV}$} & 14 & 8 of national interest & & & \\
\hline & NPNRU & 6 of regional interest & $x x$ & $\mathrm{x}$ & $x x$ \\
\hline & \multicolumn{2}{|c|}{23 non NPNRU } & $x$ & o & $x$ \\
\hline \multicolumn{3}{|l|}{29 QVA } & $x$ & $\mathrm{o}$ & $\mathrm{o}$ \\
\hline
\end{tabular}

Source: Coudroy de Lille \& Bouloc, 2019. Métropole de Lyon, 2015 


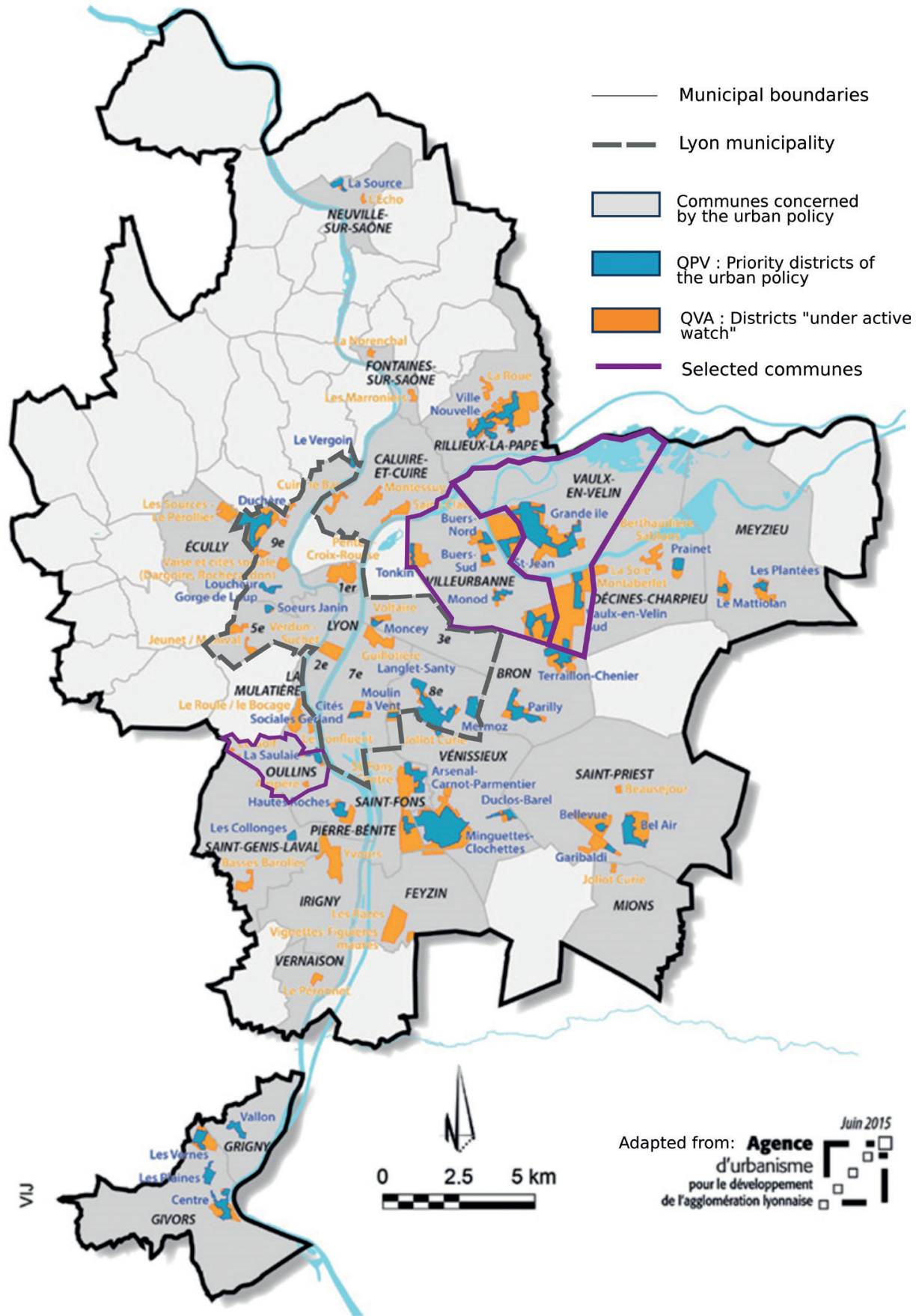

Fig. 2. Priority geography of metropolitan Lyon (QPV and QVA) in 2015 Source: adapted from Agence d'Urbanisme de Lyon, 2015 
82 URBAN RENEWAL IN POST-INDUSTRIAL DISTRICTS: THE EXAMPLE OF LYON METROPOLIS Lydia Coudroy de Lille, Caroline Bouloc

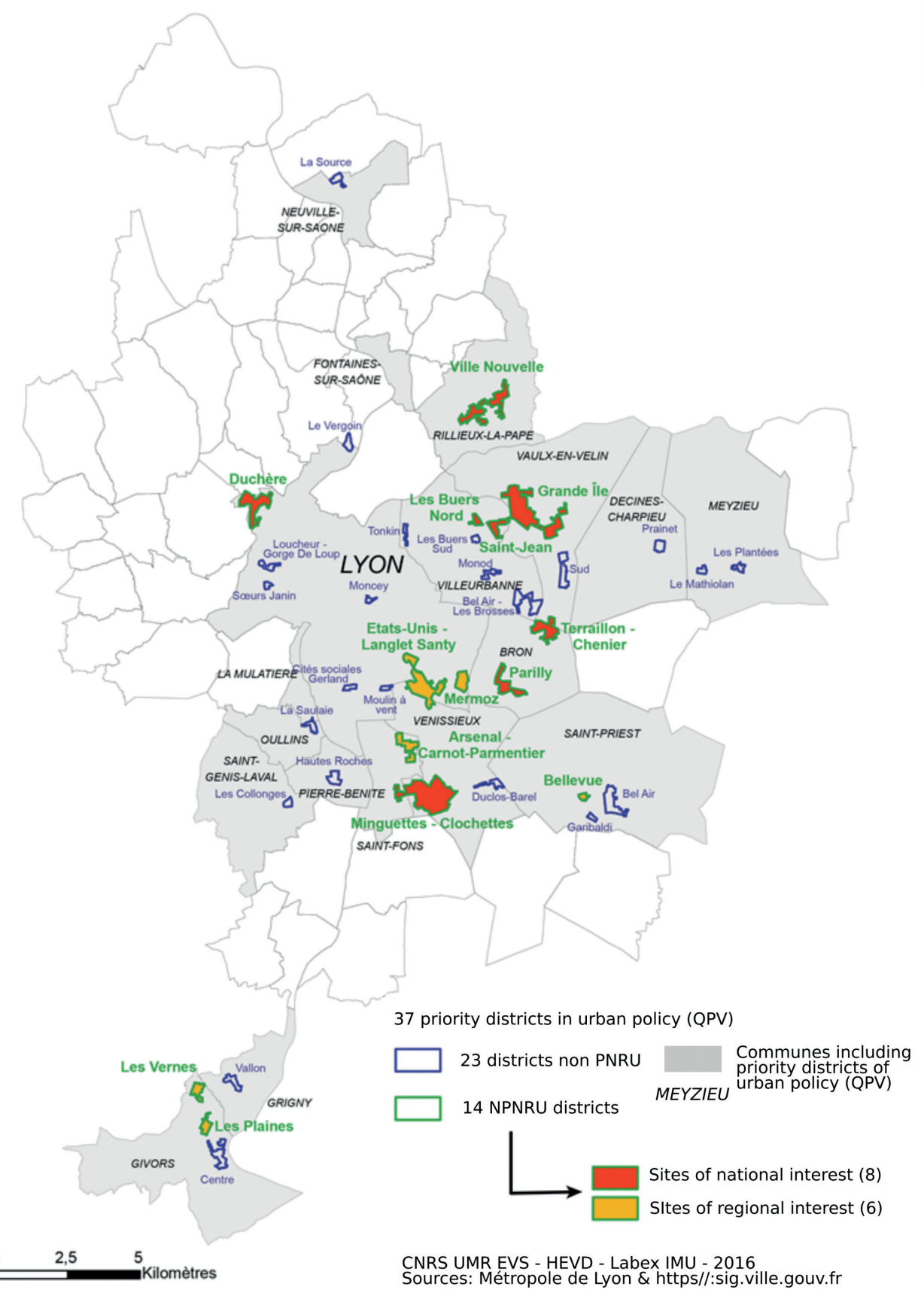

Fig. 3. Priority districts (QPV) in metropolitan Lyon in 2015 Source: Bouloc, 2018. Métropole de Lyon, 2016 


\section{Urban renewal in former industrial areas}

Former industrial areas do not raise the same questions as degraded housing estates. This is why the efforts of urban policy do not have the same aims: instead of demolishing residential blocks, a case has to be made for brownfield land, that the quality of life is damaged by industrial activity, or for the sake of accessibility. To illustrate the specific scopes of urban renewal in former industrial areas, we have focused on a small operation (La Saulaie, a district of Oullins, in the southern part of the agglomeration) and a larger one, Carré de Soie, in the north of the metropolitan area (Fig. 2).

La Saulaie is the only QPV in Oullins, whereas Villeurbanne and Vaulx-en-Velin contain a number of them (Fig. 1). Carré de Soie is a large urban project on the border between the communes of Villeurbanne and Vaulx-en-Velin and includes two QPV in these communes: Bel AirLes Brosses in Villeurbanne, and Sud in Vaulx-en-Velin (Table 3; Figs. 1 \& 4).

Table 3. Social features of communes and QPV in Lyon Metropolitan area and three communes

\begin{tabular}{|c|c|c|c|c|c|c|c|c|}
\hline & \multicolumn{2}{|c|}{ Lyon Metropolis } & \multicolumn{2}{|c|}{ Oullins } & \multicolumn{2}{|c|}{ Villeurbanne } & \multicolumn{2}{|c|}{ Vaulx-en-Velin } \\
\hline & Total & $\begin{array}{l}\text { All } \\
\text { QPV }\end{array}$ & Total & $\begin{array}{l}\text { QPA La } \\
\text { Saulaie }\end{array}$ & Total & $\begin{array}{c}\text { QPA } \\
\text { Bel } \\
\text { Air-les }\end{array}$ & Total & $\begin{array}{l}\text { QPA } \\
\text { Sub }\end{array}$ \\
\hline Surface $\left(\mathrm{km}^{2}\right)$ & 533 & nd & 4.40 & 0.40 & 14.50 & 0.33 & 20.90 & 0.34 \\
\hline $\begin{array}{l}\text { Population } \\
\text { density (inh./ } / \mathrm{km}^{2} \text { ) }\end{array}$ & 2,508 & nd & 5,925 & 3,340 & 10,151 & 15,291 & 2,109 & 6,630 \\
\hline Polulation in 2010 & $1,336,994$ & 159,860 & 26,072 & 1,336 & 147,192 & 5,000 & 44,087 & 2,241 \\
\hline $\begin{array}{l}\text { Population }<24 \\
\text { yeara old }\end{array}$ & 39 & 34 & 34 & 38 & 36 & 49 & 39 & 35 \\
\hline $\begin{array}{l}\text { Foreign } \\
\text { population (\%) }\end{array}$ & 9 & 21 & 6 & 21 & 12 & 17 & 19 & 24 \\
\hline $\begin{array}{l}\text { Share of } \\
\text { households in } \\
\operatorname{HLM~(2013)~}\end{array}$ & 20 & 66 & 15 & 37 & 20 & 19 & 47 & 33 \\
\hline $\begin{array}{l}\text { Share of vacant } \\
\text { dwellings (2013) }\end{array}$ & 7 & nd & 9 & 19 & 8 & 10 & 7 & 5 \\
\hline $\begin{array}{l}\text { Poverty rate } \\
(2013)\end{array}$ & 16 & 36 & 13 & 49 & 18 & 36 & 31 & 37 \\
\hline $\begin{array}{l}\text { Share of } \\
\text { employed } \\
\text { persons in the } \\
15-64 \text { population }\end{array}$ & 63 & 50 & 67 & 53 & 60 & 49 & 47 & 57 \\
\hline
\end{tabular}




\begin{tabular}{|l|c|c|c|c|c|c|c|c|}
\hline \multirow{2}{*}{} & \multicolumn{2}{|c|}{ Lyon Metropolis } & \multicolumn{2}{c|}{ Oullins } & \multicolumn{2}{c|}{ Villeurbanne } & \multicolumn{2}{c|}{ Vaulx-en-Velin } \\
\cline { 2 - 8 } & Total & $\begin{array}{c}\text { All } \\
\text { QPV }\end{array}$ & Total & $\begin{array}{c}\text { QPA La } \\
\text { Saulaie }\end{array}$ & $\begin{array}{c}\text { QPA } \\
\text { Total } \\
\text { Air-les }\end{array}$ & Total & $\begin{array}{c}\text { QPA } \\
\text { Sub }\end{array}$ \\
\hline $\begin{array}{l}\text { Median annual } \\
\text { income of } \\
\text { households (2013) }\end{array}$ & 21,110 & 10,436 & 20,552 & 8,882 & 18,606 & 11,474 & 12,436 & 11,118 \\
\hline
\end{tabular}

Sources: Coudroy de Lille, adapted from INSEE and sig.gouv.fr

La Saulaie and Carré de Soie are parts of very different communes within the metropolitan area. Oullins is a commune of 26,000 inhabitants conterminous with Lyon. It is not a poor municipality (the median income is very close to the metropolitan), and the share of foreign population is only $6 \%$ compared to $9 \%$ in the metropolisat large (Table 3 ). It is divided into a residential area in the west, on the slope above the Rhône, and the industrialized riverbanks in the east, including the small area called La Saulaie (Fig. 5). In the middle stands a suburban railway station and a small town centre. La Saulaie is marked by the industrial history of the twentieth century (production and maintenance of locomotives), and is isolated from the rest of the city by strong morphological barriers, which delineate it:

- $\quad$ in the North the Yzeron river and former large train sheds and repair halls (closed in 1989) close to the commune La Mulatière (Fig. 4);

- $\quad$ in the east, the Rhône valley flanked by the highway A7, the busiest motorway in France ${ }^{6}$, connecting, among others, Bruxelles and Paris to Marseille and the French Riviera;

- $\quad$ in the west, railways.

\section{Tackling poverty in La Saulaie}

La Saulaie can be considered as a pocket of poverty, where households living in poverty account for $49 \%$ of households. It is one of the poorest QPVs in the whole metropolitan area (the median annual income of households is below $€ 9,000$ ), even after a programme of investment in the late 1990s, which aimed to attract companies to its southern districts. The population has decreased by $20 \%$ since 1990, explaining why $19 \%$ of dwellings stand empty. Although almost $40 \%$ of dwellings are social housing, these are in older small blocks. Some of them were demolished during the first urban renovation efforts in the 1980s and replaced by new social housing. It will still be a while before the numerous old houses owned by impecunious private landlords will be renovated.

However, two major urban changes are in progress in the commune. The subway was extended to Oullins railway station in 2014, making this station a secondary hub, directly connected to the main railway station Lyon Part-Dieu in 20 minutes. This has already affected the supply of commercial and residential property in the town centre. The second change is

${ }^{6} 115,000$ vehicles per day in average. 


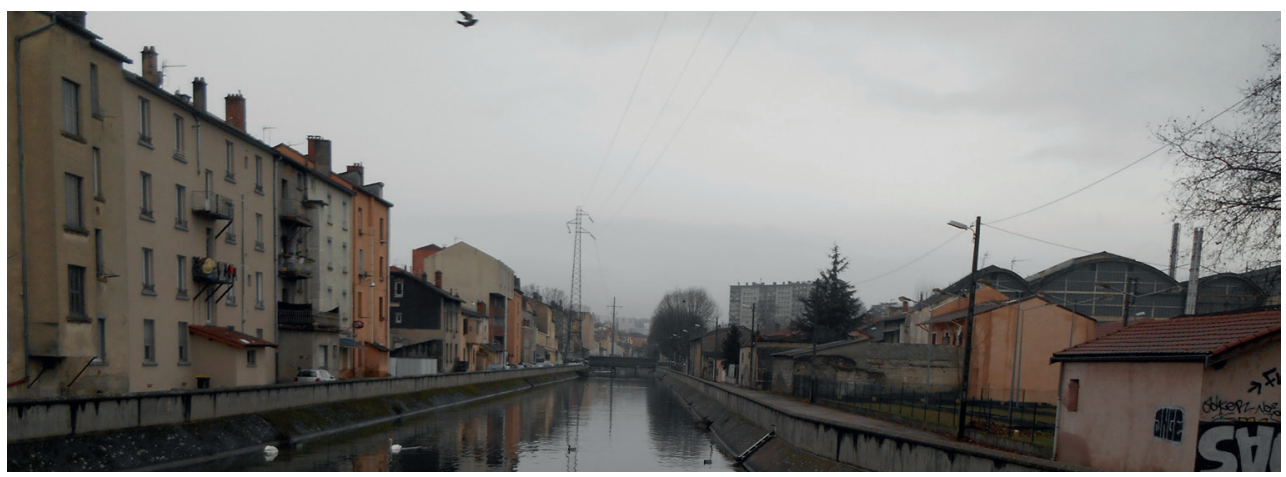

Fig. 4. Old housing blocks in La Saulaie (left side) along the river Yzeron

Source: Coudroy de Lille, 2018
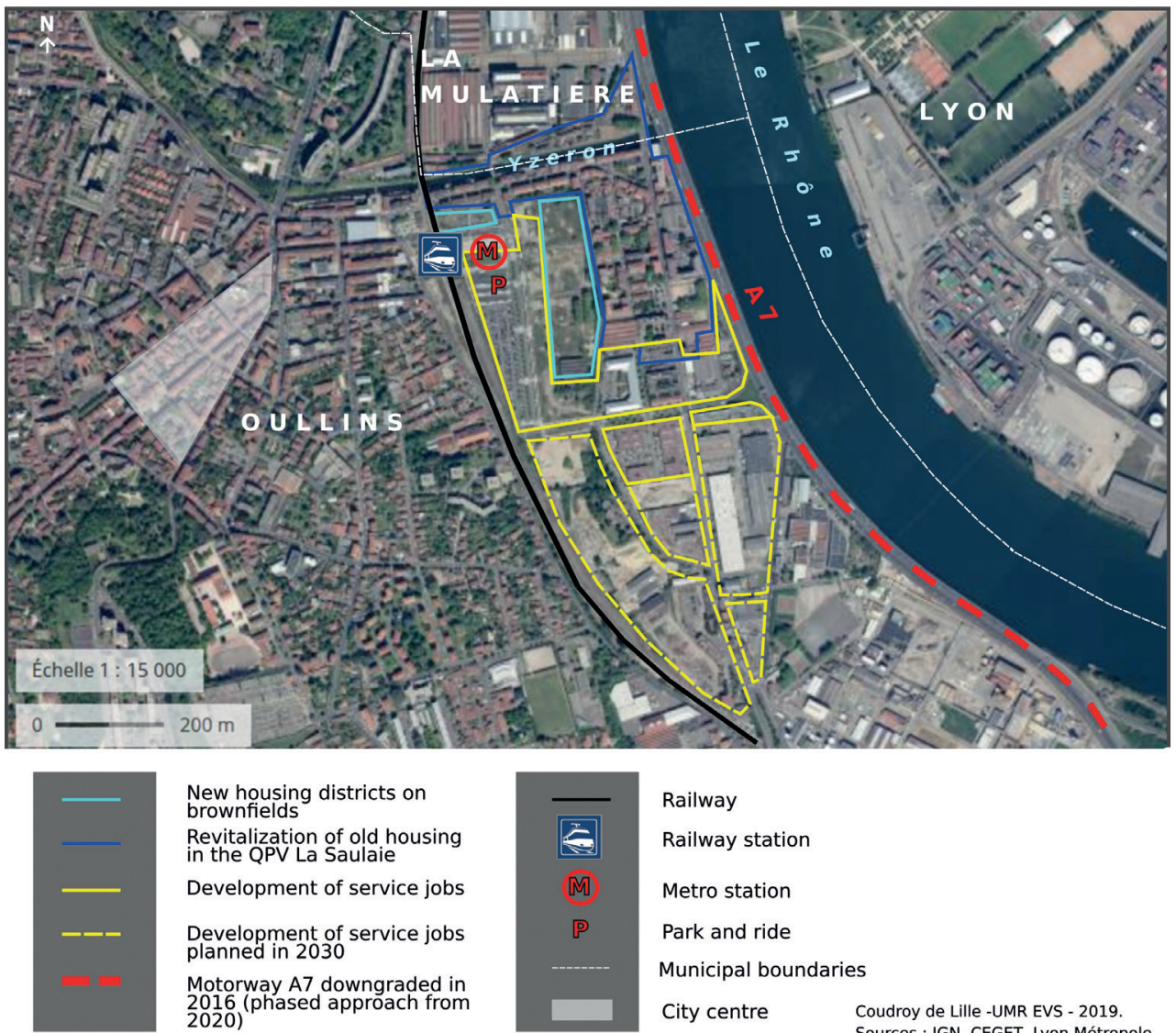

New housing districts on brownfields

Revitalization of old housing in the QPV La Saulaie

Development of service jobs

Development of service jobs planned in 2030

Motorway A7 downgraded in 2016 (phased approach from 2020)

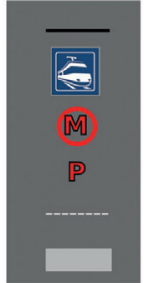

Railway

Railway station

Metro station

Park and ride

Municipal boundaries

City centre

Coudroy de Lille -UMR EVS - 2019. Sources : IGN, CEGET, Lyon Métropole

Fig. 5. Urban change in La Saulaie (Oullins) Source: Coudroy de Lille, 2019 
the future declassification of the A7 highway, passed in 2016 by the French government; the "Sun motorway" will become a boulevard for environmentally friendly transport, and create opportunities for bridges over the Rhône. The urban policy's aim for 2023 is to improve La Saulaie's connection to the metro station. Thanks to new streets and above all through urbanizing a vast brown field site separating it from the metro. It also aims to continue to attract businesses to the economic activity zone in the southern part. This project is expected to create 3,000 jobs, mainly in office buildings, and a hotel has already been built. The banks of the river Yzeron are to be developed and embellished. Compared to other QPVs in metropolitan Lyon, La Saulaie benefits from a vibrant civic life, involving many social economic organizations, because it needs social change much more than urban transformation. Demolition and reconstruction projects run to time and mostly consist of small private blocks. At all points, the metropolitan authorities exercise their right to pre-emption to avoid the impoverishment of the district, and to drive out slum owners. A new offer of attractive dwellings will appear in the brown field site close to the metro station and later in the former train shed on the left bank of the Yzeron (Fig. 6).

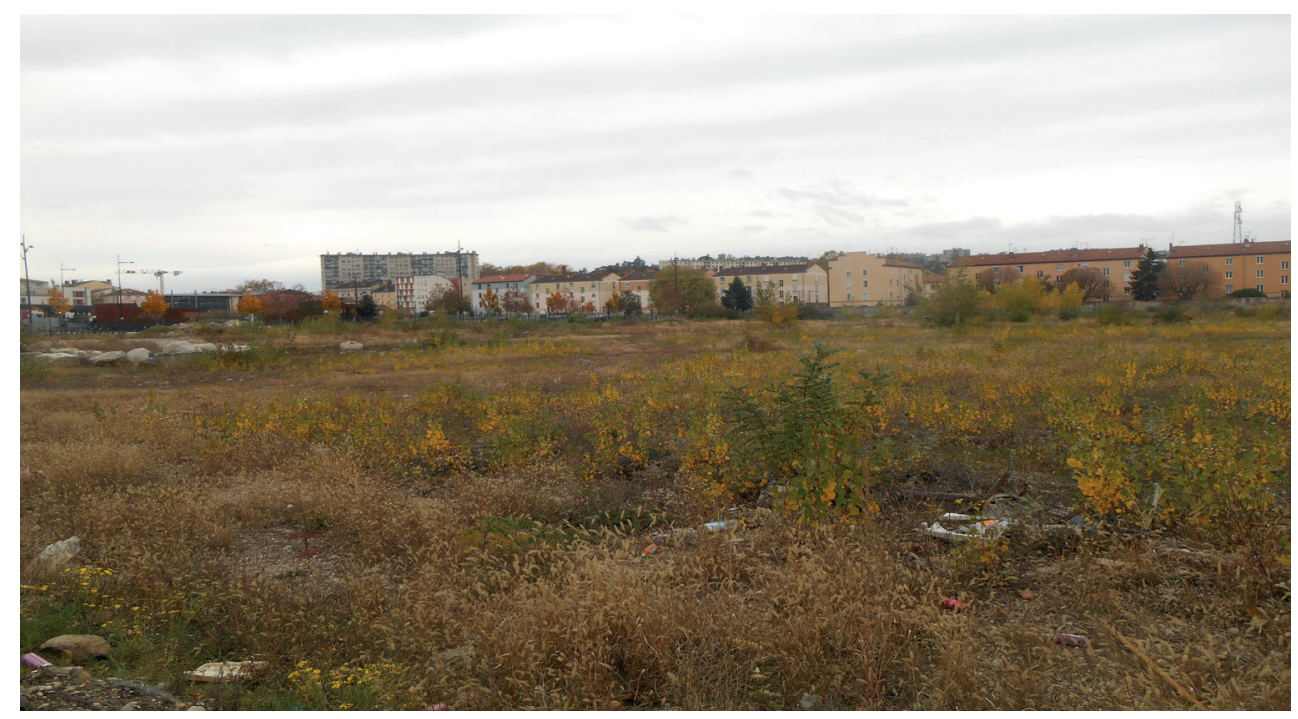

Fig. 6. A brownfield site between the metro station Gare d'Oullins and La Saulaie (background) Source: Coudroy de Lille, 2018

\section{Making of Carré de Soie a secondary hub in the metropolis}

Carré de Soie lies on the border between Villeurbanne, the biggest suburb of Lyon (147,000 inhabitants) and Vaulx-en-Velin, one of the "historical core" of riots and of urban policy in the metropolis (44,000 inhabitants). These two communes have several other QPVs because of their size and their social profile. Vaulx-en-Velin is the poorest of the communes in which the urban policy applies, due especially to the presence of large housing estates in the northern 
part of the commune on the right bank of the Rhône; and the median income for the whole commune is only $€ 12,436$. Villeurbanne is more complex: the town centre in the western part is very dynamic, close to the business district Lyon Part-Dieu, this is why on the whole, the commune cannot be considered as a poor one (with a median annual income of $€ 18606$ ). The area named Carré de Soie is on the periphery of Vaulx-en-Velin and Villeurbanne (Fig. 7). It was urbanized only at the beginning of the twentieth century around a huge artificial textile factory, opened in 1925 (TASE for Textiles Artificiels du Sud-Est), which employed 3,000 workers in 1929. TASE was located in this periphery because of the pollution generated by its activity. It attracted immigrants from all over Europe, some of them living in the "small TASE city", a garden city adjoining the factory, others in the "big TASE city", a few blocks of a HLM housing estate built in the interwar period. Other factories completed the urbanisation, but the area Carré de Soie remained sparsely populated in comparison with the centre of Villeurbanne and Vaulx-en-Velin until the end of the twentieth century. The TASE factory was closed in 1980.

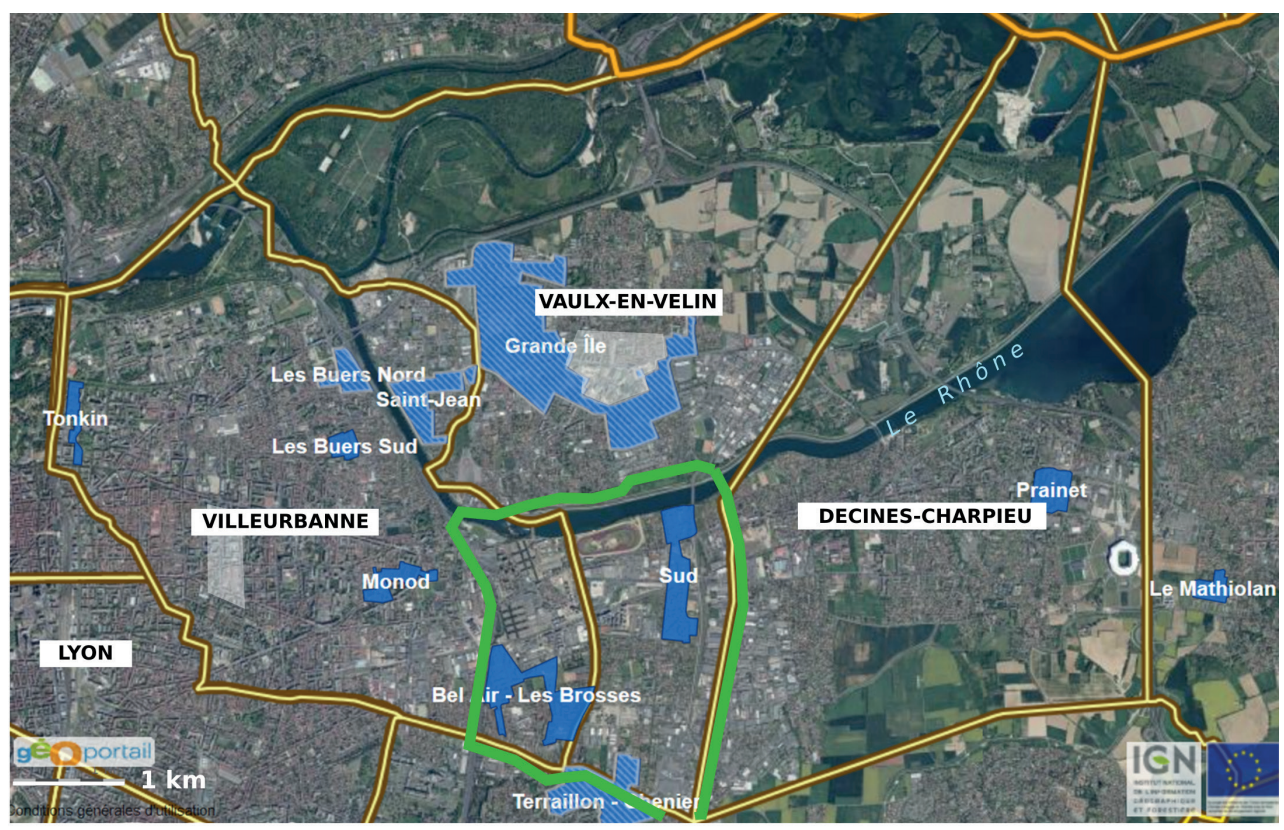

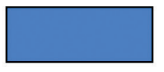

Priority districts in the urban policy (QPV)

Priority districts in the urban policy involved in the New Plan of Urban Renewal (NPNRU)

Carré de Soie project area
Municipal boundaries

VILLEURBANNE Name of communes

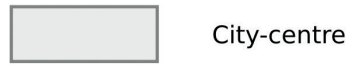

Coudroy de Lille - UMR EVS - 2018. Adapted from https://sig.ville.gouv.fr

Fig. 7. The Carré de Soie in Villeurbanne and Vaulx-en-Velin 
After the difficult period of the 1980s and 1990s mentioned above, the prospects for developing the eastern suburbs witnessed a turning point at the beginning of this century. Firstly, the demographic and economic situation of the metropolitan area was such that it favoured searching for sites for urban extension. On a metropolitan scale, it appeared that the area Carré de Soie, which had always been regarded as the periphery of both eastern suburban communes, could now become a new hub for agglomeration (Fig. 10). It is located midway between the Lyon business district Part-Dieu and the international airport and was full of vacant and mutable tenements at the beginning of the twenty-first century. The area, which was known only as the TASE territory, was therefore renamed Carré de Soie. ${ }^{7}$ The first stage of the project was the creation of a multimodal public transport hub. Indeed, a railway line already existed for the purposes of both industry and a maintenance site for the metro; this is why a new tram line could open in 2006 and the railway line could be up and running by 2010 as a tram and train link to the airport. At first, this infrastructure led to a kind of no man's land in a desolate landscape, due to the first phase of the TASE demolition in 2008 (which stopped after the inhabitants protested against it). The second stage was the opening of a shopping mall and leisure centre in 2009. The third stage will consist of building of new areas for housing, offices, and workshops, among others in the former TASE factory (Figs. 8\&9). The programme includes the revitalization of old houses and small blocks in the QPVBel Air-Les Brosses in Villeurbanne, and above all building a new housing supply on free plots. For the

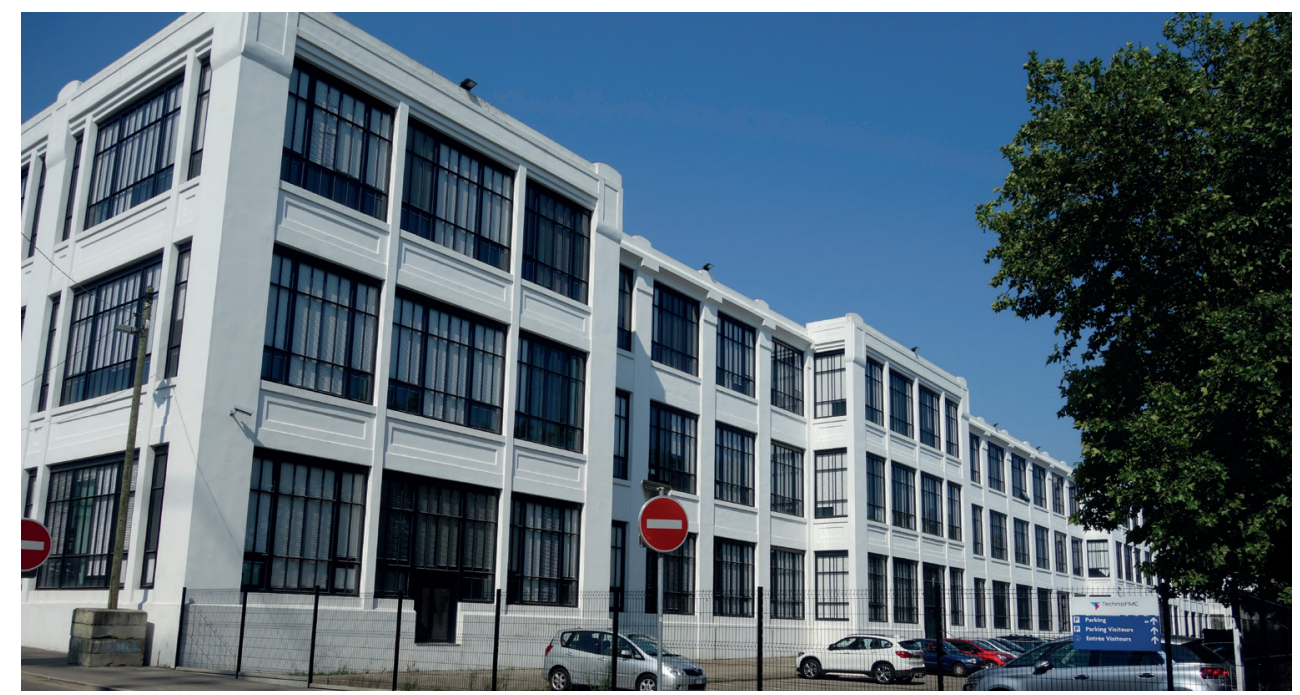

Fig. 8. Offices in the former TASE factory, La Soie

Source: Coudroy de Lille, 2018

\footnotetext{
${ }^{7}$ Carré de Soie, meaning literally "Silk square" is a word game. The area is shaped like a square and it used to be associated with the artificial silk produced at TASE. But in French, a "carré de soie" means also a "silk scarf".
} 
Vaulx-en-Velin municipality, the challenge is also to attract quality private housing in order to decrease the high share of HLM in the housing stock ( $47 \%$ of the whole commune). The rehabilitation of old HLMs from the interwar period in the southern QPV has begun, but this area is expecting further change. The façade and some parts of TASE fabric were preserved and turned into offices and workshops. Carré de Soie seems like being a "default" market, affordable to the middle class in the eastern part of the whole metropolitan area, with prices around $3,400 € / \mathrm{m}^{2}$ (as opposed to $4,400 € / \mathrm{m}^{2}$ in average in the metropolitan area and $5,200 € / \mathrm{m}^{2}$ in the city of Lyon). Half of the dwellings have been sold to inhabitants and half to investors as rental properties. Reputable companies have also chosen this attractive location, such as Veolia (which regional seat has been located in Carré de Soie since 2013), Alstom, plus many others in professional services and industry.

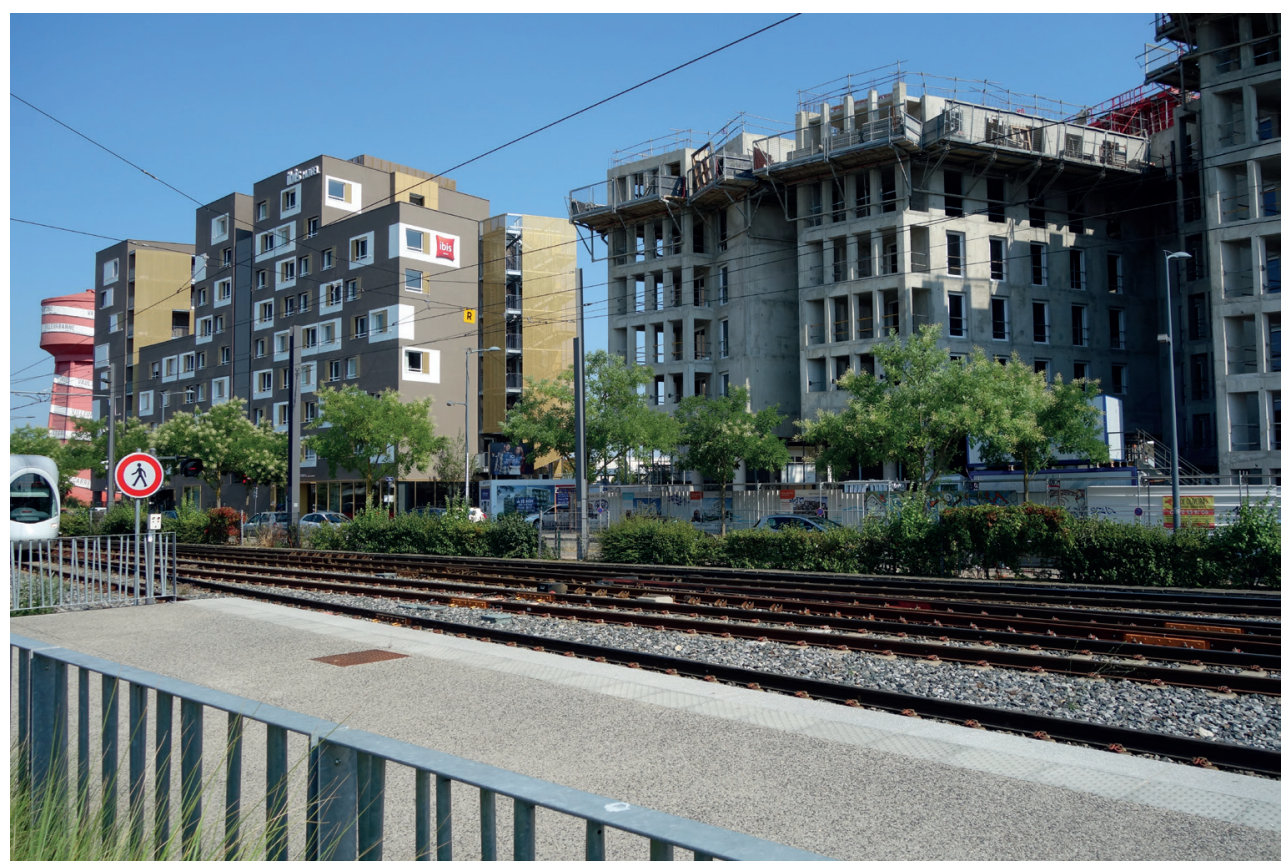

Fig. 9. Hotel, offices and housing along the tram tracks, Carré de Soie Source: Coudroy de Lille, 2018 

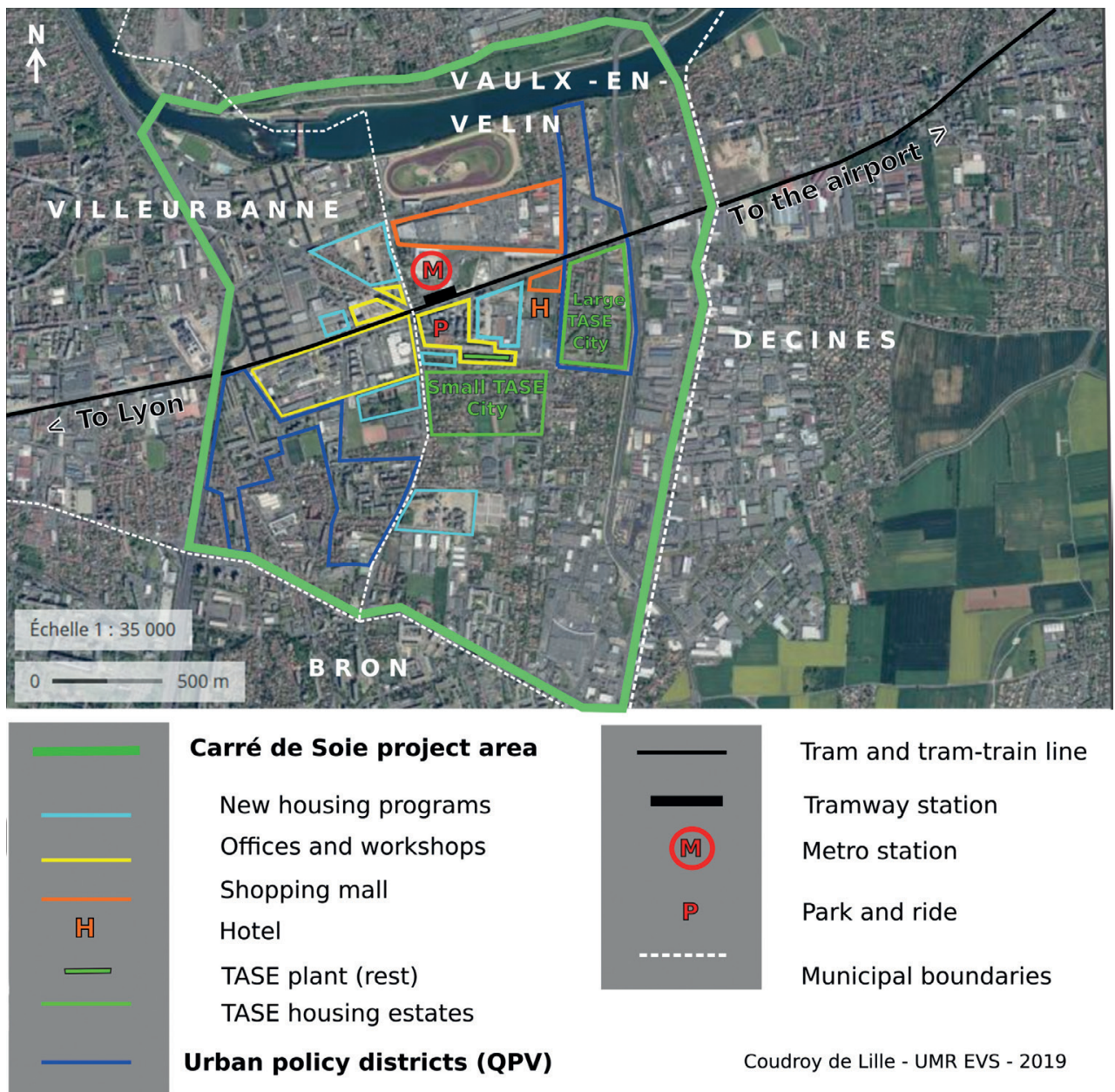

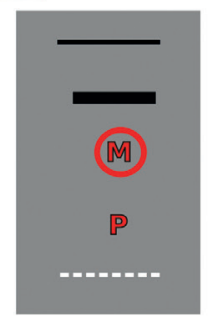

Tram and tram-train line Tramway station Metro station

Park and ride

Municipal boundaries

Fig. 10. The Carré de Soie project. State in 2019

Source: Coudroy de Lille, 2019

\section{Conclusion}

Although it is fundamentally driven by national urban policy, urban renewal is far from being pursued (and financed) on the national scale alone. It is a definitively multi-tiered process. But the involvement of further stakeholders is distinct in every city. The implementation of urban renewal in Lyon is different to what tends to happen across France: social landlords invest less but local authorities (the communes, the metropolis, the department, the region) are much more engaged. 
Priority geography in the metropolitan area shows that the main goal of urban renewal is to tackle socio-spatial segregation, whereby wealthy northern and western areas exist separately to the southern and eastern parts. Still, detailed mapping of investment in the selected communes has shown that urban regeneration is not provided only within the bounds of this priority geography: only one third of the project Carré de Soie is included in the two QPVs. The maps of revitalized areas look like complex mosaics, because the areas originally designed by the national agency (the ANRU) were exceeded by local authorities who added new plots and programmes. Therefore we can assume that national policy acts as a form of lever and encourages local public and private initiatives.

We have focussed on two post-industrial areas in metropolitan Lyon. The issues and scopes of urban regeneration are partially the same in La Saulaie and Carré de Soie. Both areas used to suffer from isolation, but for different reasons: isolation was abetted by the addition of often man-made geographical barriers due to the presence of heavy infrastructure in La Saulaie, whereas in Carré de Soie it was largely an effect of the distance from the city centre and the lack of transportation. This is why the solutions are different in each case: in La Saulaie, new pedestrianized streets should better connect the district to the metro station, and the downgrading of the motorway should connect it to the rest of the metropolitan area. In Carré de Soie, the project was launched thanks to the opening of a metro station. Of course, these two areas are not comparable per se: Carré de Soie is much bigger, and the idea is to transform this formerly peripheral industrial area into a secondary hub between Lyon and the international airport. The improvement of La Saulaie will benefit the local population above all and will have limited impact on the rest of the metropolitan area.

Post-industrial areas do not always face poverty. Whereas La Saulaie is certainly a poverty pocket, where tackling social depravation and slums is a major concern, it is not the case in Carré de Soie (which is not even the poorest area in Vaulx-en-Velin and Villeurbanne). The creation of a new housing supply close to the new metro station Carré de Soie can be seen as a tool to rebalance the housing stock at the municipal level, for example, in Vaulx-en-Velin where the share of social housing is very high. Indeed, private residential property is reasonably affordable compared to the metropolitan average, and makes Carré de Soie attractive to middle class households from the eastern part of the agglomeration. In Oullins, the spectre of gentrification looms over its future, but has not yet been observed (at 2,600 €/m² in 2018, the mean price for second-hand real estate is far below the metropolitan average) and price rises have not yet been observed. The improvement of the existing housing stock stands out as a priority action. But it is not always easy and the process of slum clearance requires time, especially where private housing and private landlords are involved.

It is worth also noting that so-called post-industrial areas do not simply cast off industry after urban regeneration programmes. In Carré de Soie, Alstom provides R\&D but also some production activities, and the Bel Air area already hosts many small workshops in high-tech. This is the same as in the activity zone in La Saulaie, where it is albeit on a smaller scale. 
Acknowledgements:

The research for this paper was completed in the labex IMU (ANR-10-LABX-0088) at the University of Lyon. It is part of the Research Programme "Habiter ensemble la ville de demain".

\section{References}

Appert M., Drozdz M., 2010, Conflits d'aménagement aux marges nord-est de la City de Londres, Hérodote, 137, 2, pp. 119-134.

Blanc M., 2007, La « politique de la ville »: une "exception française »? Espaces et sociétés, 128/129, pp. 71-86.

Body-Gendrot S., 2007, Urban 'Riots' or Urban Violence in France? Policing: A Journal of Policy and Practice, 1, 4, pp. 416-427.

Bourdon D. et al., 2013, La rénovation urbaine : pour qui ? Contribution à l'analyse des mobilités résidentielles, La Documentation Française, Paris.

Castells M., 1975, Luttes urbaines, La Découverte, Paris.

http://www.cairn.info/luttes-urbaines--9782707105912.htm

Chaline C., 1999, La regénération urbaine, PUF, Paris.

Donzelot J., Epstein R., 2006, Démocratie et participation : l'exemple de la rénovation urbaine, Esprit, 7, pp. 5-34.

Droste Ch., Lelévrier Ch., Wassenberg F., 2014, Urban Regeneration in Dutch, French and German Social Housing Areas, Social Housing in Europe, pp. 367-387.

https://onlinelibrary.wiley.com/doi/abs/10.1002/9781118412367.ch21

Edelblutte S., 2006, Renouvellement urbain et quartiers industriels anciens : l'exemple du quartier Rives de Meurthe/Meurthe-Canal dans l'agglomération de Nancy, Revue Géographique de l'Est, 46, pp. 3-4. https://rge.revues.org/1455

Epstein R., 2013, La rénovation urbaine. Démolition-reconstruction de l'Etat, Les Presses de Sciences-Po, Paris.

Fol S., 2013, La politique de la ville, un outil pour lutter contre la ségrégation ? L'Information géographique, 77, 3, pp. 6-28.

Gill I., 2010, Regional Development Policies: Place-Based or People-Centred? VOX CEPR Policy Portal https://voxeu.org/article/regional-development-policies-place-based-or-people-centred

Kaczmarek S., 2017, Demolowanie jako radykalne narzędzie w procesie rewitalizacji, Studia Miejskie, 28, 2, pp. 9-20. 
Le Garrec S., 2014, Le renouvellement urbain. La genèse d'une notion fourre-tout, Paris, PUCA. http://www.urbanisme-puca.gouv.fr/le-renouvellement-urbain-la-genese-d-unenotion-a154.html

Lees L., Ferreri M., 2016, Resisting gentrification on its final frontiers: Learning from the Heygate Estate in London (1974-2013), Cities, 57, pp. 14-24.

O'Brien P., Sykes O., Shaw D., 2015, The evolving context for territorial development policy and governance in Europe - from shifting paradigms to new policy approaches, L'Information géographique, 79, 1, pp. 72-97.

Stouten P., Rosenboom H., 2013, Urban Regeneration in Lyon Connectivity and Social Exclusion, European Spatial Research and Policy, 20, 1, pp. 97-117. 


\section{Miejska rewitalizacja dzielnic poprzemysłowych: przykład metropolii liońskiej}

\section{STRESZCZENIE}

Rewitalizacja miejska we Francji jest często obserwowana pod kątem rozbiórki i rekonstrukcji wielkich osiedli mieszkaniowych. Niemniej, dotyczy ona również obszarów poprzemysłowych, których architektoniczne, społeczne, a także gospodarcze problemy są bardzo różne. Artykuł ma na celu przedstawienie analizy tych różnic na przykładzie dwóch studiów przypadku w obszarze metropolitalnym Lyonu, drugiej co do wielkości aglomeracji we Francji.

Po pierwsze, zarysowujemy tło polityki miejskiej w szczególności we Francji i Lyonie, wraz z mapowaniem „priorytetowej geografii” polityki miejskiej w Lyonie. Prezentowane dwa studia przypadków, La Saulaie i Carré de Soie, znajdują się na przedmieściach metropolii. Dzięki naszej analizie cech społecznych i przestrzennych oraz tych dwóch obecnie realizowanych projektów rewitalizacyjnych wykazujemy, że polityka odnowy miast we Francji jest wielowarstwowa, a przypadek Lyonu pokazuje szczególnie silne zaangażowanie władz lokalnych. Zwalczanie ubóstwa i izolacji są priorytetami w La Saulaie. W Carré de Soie wyzwaniem jest stworzenie węzła transportu publicznego, nowego rynku mieszkaniowego oraz przyciągnięcie firm do tego nowego ośrodka wtórnego. Pokazujemy również, że operacje odnowy miast nie ograniczają się do obszarów określonych przez "geografię priorytetową".

Słowa kluczowe: rewitalizacja miejska, polityka miejska, obszary poprzemysłowe, ,geografia priorytetowa", obszar metropolitalny Lyonu

$\overline{\text { Lydia Coudroy de Lille, }}$ Professor of Geography, works at the University Lumière Lyon 2 and at the CNRS research unit UMR 5600 Environnement Ville Société. She has conducted many studies into urban geography and housing in Central and Eastern Europe, with a particular emphasis on Poland. She has been leading the research project «Habiter Ensemble la Ville de Demain » (Living Together in the City of Tomorrow) in the Labex IMU with sociologists, economists, geographers, as well as public and private stakeholders in housing affairs in the Lyon metropolitan area.

Lydia Coudroy de Lille, profesor dr hab. geografii, pracuje na Uniwersytecie Lumière Lyon 2 i w centrum badawczym CNRS UMR 5600 Environnement Ville Société. Prowadziła dużo badań na temat geografii miast oraz mieszkalnictwa w Europie Wschodniej i Centralnej, przede wszystkim w Polsce. Kieruje programem badawczym pt. «Habiter Ensemble la Ville de Demain » (Wspólne życie w mieście jutra) w Labex IMU, gdzie współpracuja socjolodzy, ekonomiści, geografowie oraz publiczni i prywatni aktorzy metropolii liońskiej wdziedzinie mieszkalnictwa.

Caroline Bouloc, PhD in Social Geography. Over a period of six years, she participated in a number of research projects in the field of social geography and land use planning, in particular concerning housing policy in areas under renovation, urban governance, and public policy with respect to mobility. She has authored publications on social and residential segregation, migration on both the large scale and within cities, public policies for sustainable mobility, etc. At present, she is a project manager at the Espacité agency. Caroline Bouloc, dr geografii społecznej. Przez 6 lat pracowała zawodowo w projektach naukowych, w ramach geografii społecznej i zagospodarowania przestrzennego, zwłaszcza na temat polityki mieszkaniowej $w$ rewitalizowanych dzielnicach, zarządzania miastem oraz polityki publicznej dotyczącej mobilności. Autorka publikacji na temat segregacji społecznej i mieszkaniowej, migracji w mieście, polityki publicznej dotyczącej mobilnościzrównoważonego rozwoju itd. Aktualnie kierownik projektów w agencji Espacité. 